\title{
The potential of food derived bioactives for blood glucose management
}

\author{
C. Erraught, L. Kirwan and L. Brennan \\ Institute of Food and Health, University College Dublin, Dublin, Republic of Ireland
}

Type II Diabetes Mellitus (T2DM), is a growing global epidemic ${ }^{(1,2)}$, exacerbated by the existing obesogenic environment and physical inactivity. There is a need for improved lifestyle interventions and new dietary strategies to prevent and treat T2DM. Evidence suggests that natural bioactives may play a role in the management of blood glucose levels, by numerous mechanisms, including their insulinotropic effects ${ }^{(3-5)}$. This aim of this research was to elucidate the potential glycaemic management properties of a range of plant derived bioactives.

In vitro dose response experiments were conducted in the BRIN-BD11 cell line. Cells were cultured in T175 flasks in RPMI-1640 media with $10 \%$ (v/v) foetal calf serum, $2 \mathrm{mM} \mathrm{L}$-glutamine, $50 \mathrm{IU} / \mathrm{ml}$ penicillin, $0.05 \mathrm{mg} / \mathrm{ml}$ streptomycin, and incubated at $37^{\circ} \mathrm{C}$ and $5 \% \mathrm{CO}_{2}$. Acute insulin secretion experiments $(\mathrm{n}=4)$ were performed. Cells were incubated for 20 mins in the presence of a range of concentrations of plant bioactives including epicatechin, epigallocatechin gallate (EGCG), quercetin and genistein in $16 \cdot 7 \mathrm{mM}$ glucose. (Sigma-Aldrich Ireland Limited, Wicklow, Ireland). Insulin release was measured by ELISA assay (Mercodia Ultrasensitive Rat Insulin, Sweden). Statistical analysis was performed using SPSS V20 software.

Quercetin and genistein stimulated insulin secretion in a dose response manner, while EGCG and epicatechin did not. Exposure to quercetin $[100 \mathrm{uM}]$ induced an insulin release of $47.76 \pm 3.45 \mathrm{ng} / \mathrm{mg}$ protein which was significantly higher than the control, $16.7 \mathrm{mM}$ glucose, with an insulin release of $24.31 \pm 1.96 \mathrm{ng} / \mathrm{mg}$ protein, $p<0.05$. Exposure to a combination of quercetin [100uM] and genistein $[20 \mathrm{uM}]$ demonstrated a synergistic effect on insulin release of $65.892 \pm 8.75 \mathrm{ng} / \mathrm{mg}$ protein; which was significantly higher, $p<0.05$, than quercetin $[100 \mathrm{uM}]$ alone.

The potential of quercetin and genisteins' synergistic effect should be investigated in vivo and the cellular mechanisms are currently being investigated. This research will lay the foundations for the development of innovative foods, which will be targeted at prediabetics and people with T2DM.

1. World Health Organisation. Obesity and overweight. Fact sheet №311: WHO; 2013 [Available from: http://www.who.int/mediacentre/factsheets/ fs311/en/.

2. World Health Organisation. Diabetes, Fact sheet $N^{\circ} 312,2015$ [Available from: www.who.int/mediacentre/factsheets/fs $312 / \mathrm{en}$ ].

3. Zheng XX, Xu YL, Li SH, Hui R, Wu YJ, Huang XH. Effects of green tea catechins with or without caffeine on glycemic control in adults: a meta-analysis of randomized controlled trials. Am J Clin Nutr. 2013;97(4):750-62.

4. Turrini E, Ferruzzi L, Fimognari C. Possible Effects of Dietary Anthocyanins on Diabetes and Insulin Resistance. Curr Drug Targets. 2015.

5. Dragan S, Andrica F, Serban MC, Timar R. Polyphenols-rich natural products for treatment of diabetes. Curr Med Chem. 2015;22(1):14-22. 